ROCZNIKI FILOZOFICZNE

Volume LXIX, issue 3-2021

DOI: https://doi.org/10.18290/rf21693-7

MAREK DOBRZENIECKI

DEREK KING

\title{
THE THEOLOGY OF HIDDENNESS: J. L. SCHELLENBERG, DIVINE HIDDENNESS, AND THE ROLE OF THEOLOGY*
}

\section{INTRODUCTION}

For a long time, the ambivalence of the world was a temptation to vindicate atheism. The ambiguity with respect to the source of the existence of reality raised questions like: "Could such a universe be the work of perfect love and perfect power? Could this be a way to love and express love: to leave the loved one in a bewildering uncertainty over the very existence of the allegedly loving God?", or: "What reason could there be for unbelievers always to have reasonable grounds for their hesitation?"2 In his hiddenness argument J. L. Schellenberg argues that there is no such reason, and he concludes that the existence of a personal God is incompatible with the existence of nonresistant nonbelievers. ${ }^{3}$

MAReK DoBrZENIECKI, PhD, Catholic Academy in Warsaw, Collegium Joanneum; correspondence address: ul. Dewajtis 3, 01-815 Warszawa, Poland; e-mail: mdobrzeniecki@pwtw.pl; ORCID: https:// orcid.org/0000-0002-1992-3222.

DEREK S. KING, PhD Candidate at the University of St Andrews; correspondence address: 213 Clay Ave., Apt. 11, Lexington, KY 40502, USA; e-mail: dsk4@st-andrews.ac.uk; ORCID: https:// orcid.org/0000-0002-3381-2799.

* The author acknowledges the financial support of the National Science Centre, Poland, for the research project "Deus absconditus - Deus revelatus," grant no 2018/29/B/HS1/00922.

${ }^{1}$ Ronald Hepburn, "From World to God," Mind 72, no. 285 (1963): 50.

2 Terence Penelhum, God and Skepticism (Dordrecht: Reidel, 1983), 158.

${ }^{3}$ J. L. Schellenberg, Divine Hiddenness and Human Reason (Ithaca, NY: Cornell University Press, 1993), 83; see also Schellenberg, Wisdom to Doubt. A Justification of Religious Skepticism (Ithaca, NY: Cornell University Press, 2007), 204-6; SCHELlenberG, The Hiddenness Argument. Philosophy's New Challenge to Belief in God (Oxford: OUP, 2015), 103. 
On the other hand, theistic opponents of the argument could invoke a fragment of Pascal's Pensées: "Let them at least learn what is the religion they attack, before attacking it. If this religion boasted of having a clear view of God, and of possessing it open and unveiled, it would be attacking it to say that we see nothing in the world which shows it with this clearness." 4 According to Pascal the teaching of the Church assumes the hiddenness of God, and hence, from the Christian point of view there is nothing surprising in the fact of nonbelief in the world governed by an omnipotent and all-loving God. In what follows we shall explore Pascal's idea by showing how certain doctrines of Christianity explain the compatibility of the simultaneous existence of both God as well as nonresistant nonbelievers.

We shall begin by noticing that the hiddenness argument is especially challenging for the Christian theology (section 1), then we shall invoke certain theological doctrines that shed light on how God's openness to relationship is compatible with nonresistant nonbelief (section 2). In our opinion the following doctrines are helpful in this regard: the doctrine of the Incarnation (subsection 2a), of the Church as a Body of Christ (subsection 2b), and of the Original Sin (subsection 2c). Next, we shall face Schellenberg's challenge according to which theistic rebuttals underestimate the divine limitlessness of resources (subsection 2d). The objection is the following: a theistic defense ${ }^{5}$ usually consists in identifying greater goods that God achieves due to his hiddenness. Schellenberg responds to such a defense by the so called "accommodation strategy", that is by pointing out that an omnipotent God could have created a world in which both - the alleged greater goods as well as interpersonal relationships between the Creator and finite persons-occur. In the final part of the paper we shall analyze how the hiddenness argument could positively influence theology, especially its understanding of the divine revelation (section 3).

\section{PERSONAL RELATIONSHIP AND THE CHRISTIAN GOD}

To put it simply, Schellenberg's argument rests on two fundamental premises. According to the first one (from now on P1), a personal, loving God would always be open to meaningful relationships with finite persons capable

\footnotetext{
${ }^{4}$ Blaise PASCAL, Pensées, trans. W. F. Trotter, available online in Christian Classics Ethereal Library, accessed March 27, 2021, http://www.ccel.org/ccel/pascal/pensees.html, sec. 194.

${ }^{5}$ We understand the term "defense" as referring to a possible explanation for the fact that God allows a nonresistant nonbelief to occur in the actual world (see Peter VAN Inwagen, "The Problem of Evil, the Problem of Air, and the Problem of Silence," Philosophical Perspectives 5 (1991), 141.
} 
of participating in them. ${ }^{6}$ The divine openness involves removing all obstacles that hinder a person from entering in an interpersonal relationship with God, including the lack of belief in his existence. Hence, the expectation is that a loving God would not allow nonresistant nonbelief to occur. In the second premise (from now on P2) Schellenberg notices that there are large numbers of nonresistant nonbelievers. According to him, one is able to explain this fact only under the assumption that theism is false-there exists no God.

It is worth mentioning that objections to the hiddenness argument are raised also by atheists. For example, Theodore Drange rejects P1. He claims that there is no contradiction in the statement: " $\mathrm{X}$ loves $\mathrm{Y}$, but $\mathrm{X}$ does not want $\mathrm{Y}$ to be aware of X's existence." If human beings are incapable of comprehending God, then there is no oddity in the above statement. In his view it is disputable whether God has to be perfectly loving toward humanity. Roger Pouivet (obviously, a theist) adds to these remarks that there is no reason for an advocate of philosophical theism to accept a tacit assumption of the hiddenness argument according to which one should model the conception of divine love on the analogies taken from human interactions. ${ }^{8}$ Drange concludes that Schellenberg's argument is not aimed at the existence of God in general, but it rather establishes the nonexistence of God of the Christian doctrines. ${ }^{9}$

We agree with Drange that the main target of Schellenberg's argument is the God of the Judeo-Christian Bible. The Christian revelation shows that the ideal of relational love is properly (even if not univocally) applicable to God. The birth of the Son of God was announced as the coming of Emmanuel which means "God with us" (Matt. 1:23), ${ }^{10}$ and in the beautiful allegory from the Book of Revelation Jesus says: "Here I am! I stand at the door and knock. If anyone hears my voice and opens the door, I will come in and eat with that person, and they with me" (Rev. 3:20). Christianity introduced the concept of human beings as the children of God (1 John 3:2) and God as the heavenly Father of the humanity (Matthew 6:9), which contrary to Pouivet's defense, validates parental analogies that Schellenberg makes in order to justify P1. Moreover, the authors of the New Testament agree that the ultimate goal of a human being is to see God face to face. St. Paul wrote for example: "For

\footnotetext{
${ }^{6}$ SCHELlEnBERG, Hiddenness Argument, 40.

${ }^{7}$ Theodore Drange, Nonbelief and Evil (New York: Prometheus Books, 1998), 267.

${ }^{8}$ Roger Pouivet, "Against Theistic Personalism: What Modern Epistemology Does to Classical Theism,” European Journal for Philosophy of Religion 10, no. 1 (2018): 3.

${ }^{9}$ Drange, Nonbelief and Evil, 42.

${ }^{10}$ Translation according to the New International Version (Biblica, The International Bible Society, 2011).
} 
now we see only a reflection as in a mirror; then we shall see face to face. Now I know in part; then I shall know fully, even as I am fully known" (1 Cor. 13:12). ${ }^{11}$ It gives credibility to Schellenberg's claim that participating in an interpersonal relationship with the Creator is an unsurpassable good for a human being and it reinforces his supposition that no "greater good" strategy will work with respect to the hiddenness argument. We would also add that the author of the Gospel of John agrees that there is something problematic in God leaving large numbers of people in the darkness of nonbelief: "Then Judas (not Judas Iscariot) said, 'But, Lord, why do you intend to show yourself to us and not to the world?" (John 14:22). ${ }^{12}$ This substantiates the claim that there is something in the hiddenness argument that demands an answer from a Christian theologian.

The suspicion that the hiddenness argument brings an accusation against Christian doctrines in particular is also indirectly confirmed by theists who respond to the argument from the perspectives of other forms of religious monotheisms, especially Islam and Judaism. For example, Jon McGinnis invokes the contention of Muslim theologians that the only suitable object of divine love is God himself and, more importantly, that the concept of interpersonal relationship with God would not make much sense for them, because it assumes that God is a person: "Already red flags should pop up, for the doctrine of God's personhood was forged in the heat of debates about the triune nature of God, a doctrine unique to Christianity among the Abrahamic religions." ${ }^{\text {"13 }}$

Therefore, in our opinion the hiddenness argument puts to the test not theism as such, but Christian theism; that is, theism that acknowledges the attribute of the divine openness to participate in personal relationships with human persons. Our task at hand is to defend the consistency of Christian theology confronted with the fact of nonresistant nonbelievers. In our view not only this project is feasible, it also shows that theological ideas can be fruitfully applied in philosophical debates.

\footnotetext{
${ }^{11}$ See also Matthew 5:8 or 1 John 3:2.

12 There are also passages which suggest the opposite. Jesus intentionally conceals from some people or keeps his mission secret. Cf. Matthew 13:10-11.

13 Jon McGinnis, "Divine Love in Medieval Islamic Lands," in Hidden Divinity and Religious Belief. New Perspectives, ed. Adam Green and Eleonore Stump (Cambridge: CUP, 2015), 167.
} 


\section{THE ROLE OF THEOLOGY: FRUITFUL APPLICATIONS OF THEOLOGICAL IDEAS IN THE HIDDENNESS DEBATE}

In this section, we offer four avenues for a theological response to Schellenberg's hiddenness argument. As avenues for response, they are not complete, but rather sketches, or gestures, from which, in our view, a more robust response could be formulated.

\subsection{THE INCARNATIONAL RESPONSE}

John Paul II, when asked why God does not reveal himself more clearly, answered by indicating the dogma of the Incarnation: "Could God go further in his stooping down, in his drawing near to man, thereby expanding the possibilities of our knowing him? In truth, it seems that he has gone as far as possible. He could not go further. In a certain sense God has gone too far." 14

The above utterance expresses a point of view according to which there is even a greater obstacle to interpersonal relationships with God than the lack of the theistic belief: namely, the ontological difference between God and his creatures. This view is shared by Theodore Drange who speculated that if an all loving and omnipotent God existed the ontological gap between him and a human being would be far greater than between a human being and a robin. He asked: "I could make an effort toward revealing myself to the robin, but why bother?" "Because God would be far beyond our comprehension, the belief of a human being that God exists would be of little, if any, value to either God or the human being. Even if a canary "knows" that its owner exists, it does not change the fact that there cannot be any interpersonal relationship between them (at least in the literal sense of the concept).

In order for an interpersonal relationship to be formed, there has to be some degree of common ground. In general, the greater degree of ontological equality between the persons, the greater the possibility of interpersonal relationship. This presents a problem for a relational, loving God, because the ontological distance between God and human persons is immense. Therefore, if God is open to relationship with human beings, then God would be interested in reducing the ontological chasm between himself and humans. According to Christian theology this is exactly what God does in the Incarnation. The Son of God assumes the human nature in order to make friendship between man

\footnotetext{
${ }^{14}$ John Paul II, Crossing the Threshold of Hope, trans. Jenny McPhee and Martha McPhee (London: Jonathan Cape, 1994), 40.

${ }^{15}$ Drange, Nonbelief and Evil, 268.
} 
and God possible: "Friendship resting on a certain equality, persons very unequal cannot be conjoined in friendship. To promote familiar friendship then between man and God, it was expedient that God should become man, that while we know God in visible form, we may thereby be borne on to the love of His invisible perfections." ${ }^{16}$ Eleonore Stump defends this view by underlining that with regard to personal bonds the respective cognitive states are less important than being available for mutual shared attention with one another. ${ }^{17}$ One can look at the Incarnation as a way in which God made himself accessible to the experience of shared attention which is essential for establishing interpersonal relationships between man and God.

By invoking the notion of being available for mutual shared attention we could respond to a possible objection that Abraham had an interpersonal relationship with God (he heard the divine voice on multiple occasions and he responded to it), even though they were not ontologically equal. Imagine a relationship between John and Sophie which consists merely in an exchange of letters. If John or Sophie can meet in person, but they refuse to, it means that their love for each other is not perfect; that there is a defect in their relationship. It seems to us that Schellenberg would agree with us on this point. With respect to God, one should expect a perfect kind of love, and hence, the condition of personal presence or of being available for mutual shared attention applies to divine interpersonal relationships. Hence, on our view, the only relationship that deserves a title of an interpersonal relationship with God is a relationship with Christ (because God is personally present in Christ), everything that happened before could be viewed as praeparatio evangelica: a preparation of people and cultures to hear and accept the message of Christ, including the message that in Christ we meet God. From this point of view, a relationship of Abraham to God was not personal, but on the other hand this relationship was a necessary step in the process of establishing real interpersonal relationships with God.

We would add two remarks to the Incarnational Response. First, we should notice that according to this defense the very thing which gives testimony to the divine openness makes God hidden. The divine unveiling in Jesus Christ obscured God's presence in the world in some respect. Saying that Jesus of Nazareth is the only Son of God sounds paradoxical, because no amount of evidence can persuade a seeking person into a belief that a particular man

\footnotetext{
${ }^{16}$ Thomas AquINAS, Summa contra gentiles, trans. Joseph Rickaby (Catholic Primer, 2005), IV, 54, 5.

${ }^{17}$ Eleonore STUMP, The God of the Bible and the God of the Philosophers (Milwaukee: Marquette University Press, 2016), 72.
} 
possesses at the same time the divine nature. It is easy to see, then, how nonresistant nonbelief can exist. On the other hand, Christianity proclaims that for a human being to be personally related to God it is necessary to be personally related to Jesus of Nazareth. In this way the Incarnational Response provides a reason for which God would allow the occurrence of a nonresistant nonbelief in the world and rejects P1.

The second remark refers to defenses which make use of the concept of the implicit theistic belief. Some theists reject $\mathrm{P} 2$ and claim that de dicto nonbelievers could be in fact de re believers. For example, according to Poston and Dougherty if one is a beneficiary of God's blessings, then one is in de re meaningful and mutual relationship with the Creator even if one is unable to express it in a form of an explicit theistic belief. ${ }^{18}$ Schellenberg rejects this kind of response by asking why would God prefer de re theistic beliefs since de dicto beliefs give believers more confidence and are more stable ground for a interpersonal bond? ${ }^{19}$ The Incarnational Response could provide an answer to this question. It is not the case that God "prefers" de re beliefs, but since an optimal, explicit, and nonmetaphorical personal relationship with God is conditioned by faith in the dogma of the Incarnation (which by definition is voluntary), then there must be some other mediatory ways of being in a personal relationship with Jesus Christ in order for non-Christians to have a chance to be personally related to God (or, for that matter, for Christians who lived after Jesus' Ascension to Heaven. More to this point in section 2b). Terrence Cuneo recalls that the Gospel (Matthew 25:40) teaches that the way we conduct ourselves towards the least counts as our actions towards God. ${ }^{20}$ In other words, by being personally related to finite persons one is personally related to Christ, and by being personally related to Christ one is personally related to God. If that is the case, P2 is false.

\subsection{THE ECCLESIOLOGICAL RESPONSE}

Another avenue for theological response to Schellenberg's argument is an Ecclesiological Response. By Ecclesiological, we mean the response focuses on the role of the Church. The Church is called the "Body of Christ" because the individual members function as individuals (like "many parts" of a body) but also are also united to, and under the influence of, Christ (like a head to

\footnotetext{
${ }^{18}$ Ted Poston and Trent Dougherty, "Divine Hiddenness and the Nature of Belief," Religious Studies 43, no. 2 (2007), 192-93.

${ }^{19}$ SCHELlenBerG, Divine Hiddenness and Human Reason, 43.

${ }^{20}$ Terrence CunEO, “Another Look at Divine Hiddenness,” Religious Studies 49, no. 2 (2013): 153.
} 
its body). ${ }^{21}$ Leaving aside the metaphysics of such a union, the Body motif suggests that Christ's presence on earth today is partially dependent on the community of believers united to Christ (i.e. the Church). The Ecclesiological Response is aimed at P1 (that states that nonresistant nonbelief is incompatible with the existence of a perfectly loving God). ${ }^{22}$

There are at least two ways this response can unfold. The first way points to the fact that God values Church-building. ${ }^{23}$ Church-building refers to a great good that God allows: namely, the growth and development of the Church community. God values Church-building for at least two reasons. First, because the Church serves the instrumental end of increasing the knowledge of God in the world. As the Body of Christ, the building of the Church implies a growing of Christ's presence in the world. This growth yields more knowledge, of the propositional and personal sort, of God. The second reason God values Churchbuilding is that the Church is an end in itself. Augustine argues the dependence of humans on other humans for knowledge is a good thing because it allows for the intermingling of souls. ${ }^{24}$ The teaching and learning that happens in the Church, and in particular the instrumental end cited above, "ties people together in the bonds of unity." ${ }^{25}$ Given the goods that Church-building provides, a perfectly loving God may find the existence of nonresistant nonbelief something that must be allowed for these other goods to obtain.

The second way an ecclesiological response can unfold is by pointing to the fact that God may allow nonresistant nonbelief for a time in order to make a relationship with God more likely at a later time. It may be that nonresistant nonbelievers are, although nonresistant, unlikely to enter into a relationship with God at a particular time. If that is true, God may choose to remain initially hidden in order to make a lasting relationship more likely at a later time. One way he might do this is through the Church. As the Body of Christ, Christ's presence in the world to some degree depends on the Church. The Church can therefore be a mediator of God's presence to nonbelievers. That is, the Church, or the individuals within the Church, can serve as a kind of

${ }^{21}$ Cf. Paul's use in 1 Corinthians 12 and historical background of this image. Gordon D. Fee, The First Epistle to the Corinthians (Grand Rapids, MI: Eerdmans, 2014), 602; Craig S. KEENER, The IVP Bible Background Commentary New Testament (Downers Grove, IL: IVP Academic, 2014), 478-79.

${ }^{22} \mathrm{We}$ are thinking especially of premise 4, although his entire argument aims to show this inconsistency. For more, see SCHELlENBERG, The Hiddenness Argument.

${ }^{23}$ Meghan Sullivan, "The Semantic Problem of Hiddenness," in GreEn and Stump, Hidden Divinity and Religious Belief, 36.

${ }^{24}$ Augustine, On Christian Teaching, trans. R. P. H Green (Oxford: OUP, 2011), 5.

${ }^{25}$ Augustine, On Christian Teaching, 5. 
"mutual friend" - the kind that might introduce two friends, for examplebetween God and the nonbeliever. Although this would include allowing nonresistant nonbelief for a time, God would, in this case, be acting in pursuit of relationship with the nonbeliever and, therefore, in a way consistent with perfect love.

In either version of the Ecclesiological Response we offer here, God allows nonresistant nonbelief for a time in order to pursue other goods either within or through the Church. The Body of Christ is only one motif used by the theological tradition to affirm the same basic truth: God's presence in the world is somehow tied up in the community of believers known as the Church. While the Church remains imperfect, Christian theology nonetheless affirms that God's love and revelation are through the Church rather than in spite of it. If this teaching is true, then we have a reason to doubt Schellenberg's premise that the existence of a perfectly loving God is incompatible with the existence of nonresistant nonbelief.

\subsection{THE HARMATOLOGICAL RESPONSE}

Another avenue for theological response to Schellenberg is a Harmatological Response. By harmatological, we mean the response focuses on the effects of $\sin .{ }^{26} \mathrm{Sin}$ refers to the condition of humanity that infects every person (Rom. $3: 23){ }^{27}$ The effects of sin are experienced on a vertical (related to God) and horizontal (related to self or others) level. On the vertical level, sin causes a natural resistance to God and a rupture in our relationship with God. ${ }^{28}$ On the horizontal level, it causes faulty reasoning about our relationships and even our own internal, cognitive states. The Harmatological Response is aimed at P2 (that states that nonresistant nonbelief exists). ${ }^{29}$

There are at least two ways this response can unfold. The first we shall call a Hard Harmatological Response (HHR). ${ }^{30}$ HHR denies the existence of nonresistant nonbelief. For instance, Blaise Pascal says God will "make Himself known to those who should seek Him sincerely, and that He has nevertheless

\footnotetext{
26 "Harmatological" is derived from the Greek word for sin, harmartia.

${ }^{27}$ Sin can also refer to a particular thought, action, or omission, but we have in mind sin qua condition.

${ }^{28}$ For instance, see: ATHANASIUS, On the Incarnation, trans. John Behr (Yonkers, NY: St. Vladimir's Seminary Press, 2011), 77; John CALvin, Institutes of the Christian Religion, trans. F. Lewis Battles. The Library of Christian Classics 20-21 (Philadelphia: Westminster Press, 1960), 55.

${ }^{29}$ We do not rehearse Schellenberg's understanding of nonresistant nonbelief here, but for a clarification see SCHELlENBERG, "Divine Hiddenness and Human Philosophy," in GrEeN and STUMP, Hidden Divinity and Religious Belief, 23-24.

${ }^{30}$ It is "Hard" in virtue of making a stronger claim than the "Soft" version I shall introduce later.
} 
so disguised them that He will only be perceived by those who seek Him with all their heart." 31 There is enough light for those who want to see, but for those who do not God is hidden. For Pascal, sinful humans are naturally self-deceptive. He says, "we are only falsehood, duplicity, contradiction; we both conceal and disguise ourselves from ourselves." 32 The kind of self-deception Pascal imagines implies that we cannot be successful interpreters of our own cognitive states, much less the cognitive states of others. ${ }^{33}$ Any person claiming to be nonresistant, then, is actually a self-deceived resistant nonbeliever. For HHR, Schellenberg's premise that nonresistant nonbelief exists is denied.

Yet, one might find HHR to include too strong of a claim. A Soft Harmatological Response (SHR), like HHR, appeals to the effects of sin, but, unlike HHR, stops short of the stronger claim that nonresistant nonbelief does not exist. Instead, SHR adopts a kind of agnosticism about the cognitive states of others due to the lack of epistemic access that we have to them. Michael Rea, for instance, agrees that it is "fairly uncontroversial" that some people find evidence for God's existence lacking, but doubts whether they can confidently called "nonresistant." "Even though he accepts it for the sake of argument, he says the existence of nonresistant nonbelief is a claim "for which nobody could have very good evidence." 35 Although Schellenberg insists that nonresistant nonbelief is an "evident empirical fact," 36 it simply is not the case that the cognitive states of others are either evident or empirical. For SHR, Schellenberg's premise that nonresistant nonbelief exists can be neither confirmed nor denied.

HHR and SHR are only examples of how a Harmatological Response could proceed. The key to the Harmatological Response is the basic theological conclusion that sin constructs a barrier to knowing God. The extent or kind of the barrier may differ depending on one's theological commitments, but the existence of the barrier is relatively uncontroversial. For Christian theology, we

\footnotetext{
${ }^{31}$ PASCAL, Pensées, sec. 194.

32 Ibid., sec. 377.

${ }^{33}$ It is debatable whether self-deception is possible. David Kipp, for instance, says it amounts to believing, simultaneously, both $p$ and not- $p$. However, there are plausible alternatives and Schellenberg admits self-deception is at least possible. Still, he doubts whether self-deception is an example of nonresistant nonbelief since it could require a kind of unintentional deception. Resistance, for Schellenberg, must be intentional. See Schellenberg, Divine Hiddenness and Human Reason, 62; David KipP, "On Self-Deception," Philosophical Quarterly 30, no. 3 (1980), 305-17; Mary R. HAIGHT, A Study of SelfDeception (Atlantic Highlands, NJ: Humanities Press, 1980).

${ }^{34}$ Michael C. REA, The Hiddenness of God (Oxford: OUP, 2018), 17.

${ }^{35} \mathrm{REA}$, The Hiddenness of God, $17 \mathrm{n} 9$.

${ }^{36}$ SCHELlenBerg, "Divine Hiddenness and Human Philosophy," 25.
} 
are all resistant and culpable such that there is no category for a purely nonresistant (or nonculpable) nonbelief. If the Christian teaching on sin is true, then we have a reason to doubt Schellenberg's premise that nonresistant nonbelief exists.

\subsection{THE POWER OF GOD}

Schellenberg often criticizes theistic responses to his argument for employing a strategy that consists in pointing out a greater good for which God remains withdrawn and is justified in allowing nonresistant nonbelief in the world. The author of the hiddenness argument notices that any such reason must show that God is unable to procure both: a given desideratum (dependent on a particular theistic defense) as well as the universality of the theistic belief. On Schellenberg's view such a strategy "comes up against the unsurpassable immensity of the divine resourcefulness." 37

We suspect that a similar objection could be raised against responses we defended in subsections $2 \mathrm{a}-2 \mathrm{c}$. With respect to the Incarnational Response even if a critic of theism agrees with a possibility that a human being accomplishes an interpersonal relation with God by being personally related to Christ, she could ask why so many people do not believe in the divinity of Jesus. Could not God provide more credible and intersubjectively verified signs, miracles, or religious experiences that would more convincingly point to the true nature of his Son? The same question applies to the Ecclesiological Response: if God intends the Church to mediate the presence of Christ in the world, and if he desires to make the world aware of the truth of the basic doctrines of Christianity (as he should if he is indeed open to human beings), then how he permits the Church to be an untransparent and unsuccessful medium of his presence? With respect to the Harmatological Response we could ask why God created human beings with such frail free-will that they fell into the darkness of sin almost immediately after the creation?

We agree with Schellenberg that God could have created the world differently. According to the principle of sufficient reason, if God is omniscient, omnipotent, and all-loving then he has to choose to create the best possible world: "God is bound by a moral necessity, to make things in such a manner that there can be nothing better." 38 Schellenberg's critique suggests that he agrees with the

\footnotetext{
${ }^{37}$ John SCHELlEnBERG, “The hiddenness argument revisited (II)," Religious Studies 41, no. 3 (2005), 288.

${ }^{38}$ Gottfried Wilhelm LeIBNIZ, Theodicy, trans. E. G. Huggard (La Salle, IL, Open Court, 1985), 201.
} 
above principle, but he concludes that God does not exist, since God could have done something he did not do in order to improve our chances to enter into a personal relationship with him. The urgent question to answer reads as follow: "Does every deficiency of the world with respect to human's ability to communicate with God confirm that the Creator is not morally perfect?"

In our opinion it is advantageous to see how the problem of the divine freedom with respect to the act of creation was solved in Christian theology. The medieval theologians noticed that "the natural end of the divine will is the divine goodness," 39 and that he is unable not to will it. Hence, Aquinas would agree with Leibniz that there is a moral necessity in the divine will, but contrary to modern philosophers he is hesitant to judge the divine goodness with our standards of morality and our impressions of what is good. In other words, a Christian theologian would say that we can be certain of the ultimate end of the divine will, but we have to admit our ignorance with respect to what means are proportionate to this end. Certainly, the idea that there is only one way in which God can achieve his goal would seem to Aquinas false. We can suspect that he would side with these contemporary philosophers who reject the notion of the best possible world. ${ }^{40}$ It is because from his point of view there are many different possible worlds that would serve the goal of manifesting the divine goodness (one such possible worlds is a world in which the Church is a transparent sign of the divine presence and all people are devout Christians or a world in which people did not commit an original sin). The actual world is one of them and the fact that it is not the best possible world does not speak against God's moral perfection. The difference between Schellenberg and Christian theology consists in the fact that whereas the former considers the value of the world from the perspective of human interests, the latter puts God's goals in the center of its reflection. It admits that God could have improved our ability to personally relate to him, but it measures his goodness by the capacity of his creation to reflect his glory, and not by our personal interests.

\footnotetext{
${ }^{39}$ Thomas Aquinas, On the Power of God, trans. English Dominican Fathers (Westminster, MD: Newman Press, 1952), I, 5.

40 Daniel HowARD-SNYDER and Frances HowARD-SNYDER, "How an Unsurpassable Being Can Create a Surpassable World," Faith and Philosophy 11, no. 2 (1994): 260-68.
} 


\section{WHAT DOES HIDDENNESS MEAN TO THEOLOGY?}

In the context of Schellenberg's argument, divine hiddenness has (understandably) taken on a philosophy-of-religion flavor. In this context, hiddenness is decidedly a negative for God. That is, it is perceived as an evil that God must answer for. In this section, we explore a theological version of hiddenness. We first elucidate how some theologians have understood divine hiddenness. We then show how this understanding contributes to divine revelation.

The early reformed tradition did not shy away from speaking about God's hiddenness. This early tradition distinguished between God's hiddenness "in his revelation and behind his revelation." 41 The former refers to God's intentional hiding for the sake of, or even as an example of, divine revelation. The latter refers to God-in-himself as unknown (or unknowable) to us. For instance, Martin Luther has in mind hiddenness behind revelation when he says God "hides himself" and "there we have no concern." ${ }^{42}$ We simply do not have full access to God's being. Yet, for Luther God's hiddenness is also purposeful: "God hides in order to be found where God wills to be found." Calvin also connects divine hiddenness to divine revelation: "the invisible divinity is made manifest in such spectacles [that is, faith] but that we have not the eyes to see this unless they be illuminated by the inner revelation of God through faith." ${ }^{44}$ This early reformed thinking on hiddenness is later picked up by Karl Barth. He says the "hiddenness of God necessarily reminds us of our limitation." 45 For Barth, the matter is simple: "Between God and us there stands the hiddenness of God, in which He is far from us and foreign to us except as He has of Himself ordained and created fellowship between Himself and us - and this does not happen in the actualizing of our capacity, but in the miracle of His good-pleasure." ${ }^{46}$ According to this theological tradition, divine hiddenness is not a problem to be solved but is rather related to God's gracious self-disclosure.

\footnotetext{
${ }^{41}$ Brian GerRISH, "“To the Unknown God': Luther and Calvin on the Hiddenness of God," Journal of Religion 53, no. 3 (1973): 266-67. That's not to suggest that this early tradition-Luther and Calvin, in particular - explicitly made this distinction, but both kinds of hiddenness appear in their writings.

${ }^{42}$ Martin LuTHER, Martin Luther: Selections from His Writings, ed. John Dillenberger (New York: Anchor Books, 1962), 190.

${ }^{43}$ Steven D. PAULSON, "Luther on the Hidden God," Word \& World 19, no. 4 (1999), 366.

${ }^{44}$ CALVIn, Institutes of the Christian Religion, 68.

${ }^{45}$ Karl BARTh, Dogmatics in Outline (New York: Harper \& Row, 1959), 20.

${ }^{46}$ Karl BARTH, Church Dogmatics, vol. 2, The Doctrine of God, ed. Geoffrey W. Bromiley and Thomas F. Torrance (Edinburgh: Clarke, 1957), 182.
} 
Understood in this way, divine hiddenness contributes to divine revelation in at least three ways. First, God is hidden because God is a different kind of being than every other thing. A basic feature of God according to the theological tradition is that God is fundamentally transcendent. ${ }^{47}$ That is, God is fundamentally beyond - not subject to- the created order. This means God is not another object in the universe that we know like we know other objects. God's hiddenness is thus revelatory because it is also didactic: it is instructive for the kind of being God is and tunes our expectations for how we can, or should, interact with such a being. In short, divine hiddenness highlights God's fundamental difference from us.

Second, God is hidden in order to correct our incorrect understandings of God. In concert with the first reason, our understandings or conceptions of God must be corrected by God's fundamental transcendence. Nick Trakakis argues that hiddenness is revelatory because it reveals the theological mistakes we commonly make. He says, "We have become so enthralled by a mechanistic picture of reality that we cannot envision God's relationship to nature in any other way than as a demiurge, a watchmaker, one being amongst others rather than Being itself." 48 When faced with this conception of God, he continues, then "atheism" is indeed "the reasonable response," but only an atheism "that 'purifies' our preconceptions, enabling a more adequate understanding to emerge." "I9 In short, God's hiddenness leads to unfulfilled expectations about God, but these can lead us to reject an improper conception of God in favor of another, better conception.

Finally, God is hidden so that we may find him as he is: a Holy Trinity of Father, Son, and Spirit actively present in the world through the Church. According to the Christian tradition, any generic deity conceived as a large person in the sky is inadequate. Rather, God is one being in three persons and is most fully revealed in the person of Jesus Christ by the power of the Holy Spirit. So, for Barth, "in His revelation, in Jesus Christ, the hidden God has indeed made himself apprehensible." ${ }^{50}$ In this understanding, God is hidden not just for the sake of being hidden, but so that we might find him as he actually is. Divine hiddenness as a problem is another way of asking why God

${ }^{47}$ For more on what exactly we mean by divine transcendence, see Placher's helpful book: William Placher, The Domestication of Transcendence: How Modern Thinking about God Went Wrong (Louisville: Westminster John Knox Press, 1999).

${ }^{48}$ Nick TraKaKIs, "The Hidden Divinity and What It Reveals," in GreEn and StumP, Hidden Divinity and Religious Belief, 208-9.

49 TRAKAKIS, "The Hidden Divinity and What It Reveals," 209.

${ }^{50}$ BARTH, Church Dogmatics, 2:199. 
is not present to us in the ways we want or expect, but, when understood as contributing to revelation, hiddenness is rather another way of seeking God in the ways he wants or expects. Divine hiddenness is, then, a confession of dispossession in which we allow God to tell us who he is rather than trying to fit him into our preconceptions about what he must be ${ }^{51}$ Once again, Barth is worth quoting:

The Word was made flesh: this is the first, original and controlling sign of all signs. In relation to this sign, as the sign of this sign, there is also creaturely testimony to His eternal Word, not everywhere, but where His eternal Word has chosen, called and created for Himself witnesses: a testimony by the word of the prophets and apostles of his Word; by the visible existence of his people, His Church; by the Gospel which is delivered to be heard in it; by the sacraments in which this Gospel has also a physically visible and apprehensible form; and finally, by the existence of us who believe this testimony. Jesus Christ and His visible kingdom on earth: this is the greatest possibility, created by God himself, of viewing and conceiving Him, and therefore of speaking about Him. For as we men view and conceive Him, so we can speak of Him. ${ }^{52}$

Rather than a philosophical problem to be solved, this understanding of hiddenness is an invitation. That is, it is an invitation to seek God as God has made himself known and revealed himself. This is the "more adequate understanding" that Trakakis imagines. Instead of a constructed God, we received the revealed God: the Holy Trinity of Father, Son, and Spirit actively present in the world through the Church. In this understanding, God is hidden so that he may be known as he is.

\section{CONCLUSION}

In this paper, we began by suggesting that the hiddenness argument is especially aimed at the Christian doctrine of God. Then we introduced three avenues of response from within Christian theology. In particular, we suggested the incarnation, the Church, and Original Sin are all fertile grounds for response to Schellenberg. We anticipated and responded to a potential objection. Finally, we argued that divine hiddenness is not only a negative for theology-or something God must answer for-but actually has a role in illuminating God's revelation.

\footnotetext{
${ }^{51}$ BARTH, Church Dogmatics, 2:191.

52 Ibid., 199.
} 


\section{BIBLIOGRAPHY}

Aquinas, Thomas. On the Power of God. Translated by the English Dominican Fathers. Westminster, MD: Newman Press, 1952 [reprint from 1932]. Accessed March 27, 2021. https://isidore.co/ aquinas/english/QDdePotentia.htm\#1:5].

AQUinas, Thomas. Summa contra gentiles. Translated by Joseph Rickaby. Catholic Primer, 2005. Accessed March 27, 2021. https://anucs.weblogs.anu.edu.au/files/2013/11/St.-Thomas-AquinasThe-Summa-Contra-Gentiles.pdf.

Athanasius. On the Incarnation. Translated by John Behr. Yonkers, NY: St. Vladimir's Seminary Press, 2011.

Augustine. On Christian Teaching. Translated by R. P. H. Green. Oxford: Oxford University Press, 2011.

Barth, Karl. Church Dogmatics. Vol. 2, The Doctrine of God, edited by Geoffrey W. Bromiley and Thomas F. Torrance. Edinburgh: Clarke, 1957.

BARTH, Karl. Dogmatics in Outline. New York: Harper \& Row, 1959.

CALvin, John. Institutes of the Christian Religion. The Library of Christian Classics 20-21. Translated by F. Lewis Battles. Philadelphia: Westminster Press, 1966.

CunEO, Terrence. “Another Look at Divine Hiddenness.” Religious Studies 49, no. 2 (2013): 151-64. https://doi.org/10.1017/s0034412513000048.

Drange, Theodore. Nonbelief and Evil. New York: Prometheus Books, 1998.

FEE, Gordon. The First Epistle to the Corinthians. Grand Rapids, MI: Eerdmans, 2014.

GERRISH, Brian. “'To the Unknown God': Luther and Calvin on the Hiddenness of God." Journal of Religion 53, no. 3 (1973): 263-93.

GreEn, Adam, and Eleonore Stump, eds. Hidden Divinity and Religious Belief. New Perspectives. Cambridge: Cambridge University Press, 2015.

Haight, Mary. A Study of Self-Deception. Atlantic Highlands, NJ: Humanities Press, 1980.

HePBuRn, Ronald. "From World to God.” Mind 72, no. 285 (1963): 40-50. https://doi.org/10.1093 /mind/LXXII.285.40.

Howard-SNYder, Daniel, and Frances Howard-SNYDER. "How an Unsurpassable Being Can Create a Surpassable World." Faith and Philosophy 11, no. 2 (1994): 260-68. https://doi.org/ 10.5840/faithphil199411222.

John Paul II. Crossing the Threshold of Hope. Translated by Jenny McPhee and Martha McPhee. London: Jonathan Cape, 1994.

KeENER, Craig. The IVP Bible Background Commentary New Testament. Downers Grove, IL: IVP Academic, 2014

KIPP, David. “On Self-Deception.” Philosophical Quarterly 30, no. 121 (1980): 305-17. https:// doi.org/10.2307/2219524.

LeIBNIZ, Georg Wilhelm. Theodicy. Translated by E. M. Huggard. La Salle, IL: Open Court, 1985.

LuTHER, Martin. Martin Luther: Selections from His Writings. Edited by John Dillenberger. New York: Anchor Books, 1962.

MCGinNIS, Jon. "Divine Love in Medieval Islamic Lands.” In GreEN and StUMP, Hidden Divinity and Religious Belief, 157-74. 
PASCAL, Blaise. Pensées. Translated by W. F. Trotter. Accessed March 27, 2021. http://www.ccel.org/ ccel/pascal/pensees.html (Christian Classics Ethereal Library).

PAulson, Steven. "Luther on the Hidden God.” Word \& World 19, no. 4 (1999): 363-71.

Penelhum, Terence. God and Skepticism. Dordrecht: Reidel, 1983.

Placher, William. The Domestication of Transcendence: How Modern Thinking about God Went Wrong. Louisville: Westminster John Knox Press, 1999.

Poston, Ted, and Trent Dougherty. "Divine Hiddenness and the Nature of Belief." Religious Studies 43, no. 2 (2007): 183-98. https://doi.org/10.1017/S0034412507008943.

PouIVET, Roger. "Against Theistic Personalism: What Modern Epistemology Does to Classical Theism." European Journal for Philosophy of Religion 10, no. 1 (2018): 1-19.

REA, Michael. The Hiddenness of God. Oxford: OUP, 2018.

Schellenberg, J. L. "Divine Hiddenness and Human Philosophy." In GreEn and Stump, Hidden Divinity and Religious Belief, 13-32.

SchellenberG, J. L. "The Hiddenness Argument Revisited (II)." Religious Studies 41, no. 3 (2005): 287-303. https://doi.org/10.1017/S0034412505007791.

SChellenberg, J. L. Divine Hiddenness and Human Reason. Ithaca, NY: Cornell University Press, 1993.

Schellenberg, J. L. The Hiddenness Argument. Philosophy's New Challenge to Belief in God. Oxford: Oxford University Press, 2015.

SChellenBerg, J. L. Wisdom to Doubt. A Justification of Religious Skepticism. Ithaca, NY: Cornell University Press, 2007.

Stump, Eleonore. The God of the Bible and the God of the Philosophers. Milwaukee: Marquette University Press, 2016.

Sullivan, Meghan. "The Semantic Problem of Hiddenness." In Green and Stump, Hidden Divinity and Religious Belief, 35-52.

TraKaKIS, Nick. 2015. "The Hidden Divinity and What It Reveals." In GreEN and StumP, Hidden Divinity and Religious Belief, 192-209.

VAn Inwagen, Peter. "The Problem of Evil, The Problem of Air, and the Problem of Silence." Philosophical Perspectives 5 (1991): 135-65. https://doi.org/10.2307/2214093.

\section{THE THEOLOGY OF HIDDENNESS: J. L. SCHELLENBERG, DIVINE HIDDENNESS, AND THE ROLE OF THEOLOGY}

\section{Sum m a ry}

The paper explores Pascal's idea according to which the teachings of the Church assume the hiddenness of God, and, hence, there is nothing surprising in the fact of the occurrence of nonresistant nonbelief. In order to show it the paper invokes the doctrines of the Incarnation, the Church as the Body of Christ, and the Original Sin. The first one indicates that there could be greater than nonbelief obstacle in forming interpersonal bonds with God, namely the ontological chasm between him and human persons. The assumption of the human nature by the Son of God could be seen as a cure for this problem. The doctrine of the Church shows it as an end in itself, and in order for the Church to have meaning and to exist there has to be nonbelief in the world. Finally, the dogma of the Original 
Sin shows that there is no category of purely nonresistant nonbelief. The paper also addresses Schellenberg's "accommodationist strategy" from the perspective of the Christian theology and in the last part it investigates what should be the influence of the fact of the hiddenness on theology's take on the divine revelation.

Keywords: divine hiddenness; hiddenness argument; incarnation; church; original sin; accommodation strategy.

\section{BOŻE UKRYCIE I ROLA TEOLOGII}

\section{Streszczenie}

Artykuł zgłębia ideę Pascala, zgodnie z którą nauczanie Kościoła zakłada ukrycie Boga, a zatem nie ma nic dziwnego w fakcie występowania niewiary bez oporu. Aby to pokazać, artykuł przywołuje doktryny Wcielenia, Kościoła jako Ciała Chrystusa i grzechu pierworodnego. Pierwsza wskazuje, że może istnieć większa niż niewiara przeszkoda w tworzeniu więzi międzyludzkich z Bogiem, a mianowicie ontologiczna przepaść między Nim a osobami ludzkimi. Przyjęcie natury ludzkiej przez Syna Bożego może być postrzegane jako lekarstwo na ten problem. Doktryna o Kościele ukazuje go jako cel sam w sobie, z kolei aby Kościół miał sens, musi istnieć niewiara na świecie. Wreszcie dogmat o grzechu pierworodnym pokazuje, że kategoria całkowicie nieopornej niewiary jest pusta. Artykuł odnosi się również do „strategii dostosowawczej” Schellenberga z perspektywy teologii chrześcijańskiej, a w ostatniej części bada, jaki powinien być wpływ faktu ukrytości na teologiczne ujęcie Bożego Objawienia.

Słowa kluczowe: Boże ukrycie; argument z ukrycia; wcielenie; Kościół; grzech pierworodny; strategia dostosowawcza. 